\title{
CDC34 Gene
}

National Cancer Institute

\section{Source}

National Cancer Institute. CDC34 Gene. NCI Thesaurus. Code C101300.

This gene plays a role in protein ubiquitination. 